\title{
Effect of Online Business Learning, Parental, and Locus of Control on Online Entrepreneurship Interest in Vocational High School Students
}

\author{
Universitas Sebelas Maret \\ aprianfirda@gmail.com
}

Firda Aprian Ridwan, Baedhowi, Leny Noviani

\section{Article History}

accepted 31/01/2021

\begin{abstract}
This study aims to analyze the effect of online business learning, parental, and locus of control on online entrepreneurial interest in students of SMK Negeri 1 Karanganyar in the 2019/2020 academic year. The data analysis method used is descriptive quantitative, with primary and secondary data sources in the form of questionnaires and documentation. The population in this study were all students of class XI and XII on the competency of online business and marketing skills (BDP) with a sample of 105 students using the stratified proportion-tel random sampling technique. The results showed that there was a positive and significant influence between online business learning, parental, and locus of control on the interest in entrepreneurship simultaneously, with an $F$ value of 43.529 and an $R 2$ value of $56.4 \%$ with an effective contribution between online business learning $\left(X_{1}\right) 23,6 \%$, parental $\left(X_{2}\right) 19 \%$ and locus of control $\left(X_{3}\right) 13.8 \%$.
\end{abstract}

Keywords: online business learning, parental, locus of control, interest in entrepreneurship

\section{Abstrak}

Penelitian ini bertujuan untuk menganalisis pengaruh pembelajaran bisnis online, parental, dan locus of control terhadap minat berwirausha secara online siswa SMK Negeri 1 Karanganyar tahun pelajaran 2019/2020. Metode analisis data yang digunakan adalah kuantitatif deskriptif, dengan sumber data primer dan sekunder berupa angket dan dokumentasi. Populasi dalam penelitian ini adalah seluruh siswa kelas XI dan XII kompetensi keahlian Bisnis Daring dan Pemasaran (BDP) dengan sampel 105 siswa menggunakan teknik stratified proportiontel random sampling. Hasil penelitian menunjukkan bahwa ada pengaruh positif dan signifikan antara pembelajaran bisnis online, parental, dan locus of control terhadap minat berwirausaha secara secara simultan, dengan nilai $F$ hitung 43,529 dan nilai $R^{2} 56,4 \%$ dengan sumbangan efektif antara pembelajaran bisnis online $\left(X_{1}\right) 23,6 \%$, parental $\left(X_{2}\right) 19 \%$ dan locus of control $\left(X_{3}\right)$ $13,8 \%$.

Kata kunci: Pembelajaran bisnis online, parental, locus of control, minat berwirausaha

Social, Humanities, and Education Studies (SHEs): Conference Series https://jurnal.uns.ac.id/shes 


\section{INTRODUCTION}

A country that has a large population can become capital for development, but it can be a burden in development if it is not productive. The poverty rate would increase if it is left which can trigger population problems, one of them is unemployment.

According to data obtained by the Central Bureau of Statistics (BPS), the open unemployment rate in Indonesia as of August 2019 reached 7,04 million. The following is the data on the open unemployment rate based on education as of August 2019.

Table 1 Number of Open Unemployment According to Highest Education Completed as of August 2019

\begin{tabular}{lc}
\hline \multicolumn{1}{c}{ Completed Education } & Number open unemployment \\
\hline Never/ not having school/ not pass in elementary & 343.416 \\
Elementary School & 857.159 \\
Junior High School & 1.128 .018 \\
Senior High School & 1.994 .836 \\
Vocational High School & 1.727 .164 \\
Diploma I/ II/ III/ Academy & 217.331 \\
University & 738.182 \\
\hline \multicolumn{2}{c}{ Amount } \\
\hline
\end{tabular}

(Source: BPS, 2019)

Based on the data above, it shows that the number of unemployement in Vocation High School is still quite high. If we observe that the high level of unemployment in Vocation High School is caused by several factors. For example the discrepancy of requirements that occur in the labor in the business and the industrial to Vocational High School graduates, another factor is also due to the over supply of Vocational High School graduates for certain skill competencies (Jaedun et al, 2020), whereas most of industry is shifted in the labor towards digitalization (Fadli et al., 2019). These problems can be handled in various ways, encouraging the graduates to become entrepreneurs (Prima et al., 2015). Alma (2010: 5) Entrepreneurial growth in developed countries greatly affects economic growth.

Entrepreneurship can improve the country's economy because it can create jobs and reduce unemployment (Suryadi, 2019). Developing for students needs to be improved to reduce unemploymen so students are not only oriented to looking for work, but they can create their own business through entrepreneurship. The role of Vocational High School graduates in creating new entrepreneurs in Indonesia is very important because Vocation High School graduates have a high opportunity to start out a business. Vocational High School has also created graduates to be ready to work with their skills (Indriyani \& Margunani, 2019).

Based on a survey by the Indonesian Internet Service Providers Association about penetration and behavior of internet users in 2018, it was stated that the number of people using the internet in Indonesia was 171,17 million, an increase of $10,12 \%$ from the previous year which was 143,26 million. The survey results based on the age of internet users, Indonesian Internet Service Providers Association explained that the highest penetration was at the age of $15-19$, namely $91 \%$, followed by $20-24$ years at $88,5 \%$ and ages $25-29$ at $82,7 \%$, while the lowest penetration came from the group age 65 years and over $8,5 \%$ per total age surveyed. Based on these data, the highest number of internet users is in the productive age. It can be an opportunity for entrepreneurs to promote their products online, because economic activity has been supported by the internet, including in the field of entrepreneurship (Soni, 2018). 
Nowadays, internet has become a medium that provides a breakthrough to change the mindset for online entrepreneurship (Septianti \& Frastuti, 2019). In getting the profit, it is necessary to provide guidance on online entrepreneurship. Online business learning at Vocational High School provides students with knowledge about entrepreneurship online both theoretically and practically to students who are expected to foster interest in entrepreneurship online to students (Happy \& Chabib, 2021).

Students interest cultivating in entrepreneurship online through both formal and informal education (Valerio et al, 2014), one of which is through informal education that occurs in the family environment. The role of the family environment is very important in the process of student life, especially the role of parents. Parents or parental have a big role in directing decisions to be made by children (Irawansyah, 2020).

The various efforts made to increase interest in entrepreneurship both through formal education and the role of parents in supporting students to entrepreneurship online have not fully provided a strong boost to students because the real motivation comes from motivation, willingness and trust in children in their abilities.

Rotter (1966) in Pannells \& Claxton (2008) stated that this perception of personal control, or focus of control, can be explained as the degree to which an individual develops an expectation that his behavior is associated with internal or external assistance. Locus of control has a tendency, motivation that goes beyond just motivating people (Zigarmi et al, 2018). The ability to control self or focus of control is needed to control himself the cases in business. According to Winardi (2008: 33) locus of control is said to be a dimension that has an influence on entrepreneurial success. Locus of control is one of the factors that influence a person's behavior, with selfcontrol it will provide an overview of a person's belief in the determinants of their behavior, including the interest in online entrepreneurship. Cultivating students towards their interest in entrepreneurship needs to be improved so that students are able to be oriented to creating job opportunities and not only oriented to looking for work

\section{METHOD}

This research was quantitative descriptive. The sample in this study were students of Vocation High School management majoring who received online business learning, amounting to 105 students. The variables in this study consisted of independent variables, namely online business learning $\left(X_{1}\right)$, parental $\left(X_{2}\right)$, and locus of control $\left(X_{3}\right)$, as well as the dependent variable, the interest in online entrepreneurship ( $Y$ ). The data analysis used was multiple regression, $t$ test, $F$ test, and the coefficient of determination.

\section{THE RESULT AND DISCUSSION}

Table 2. Multiple Linear Regression Test Results

\begin{tabular}{|c|c|c|c|c|c|}
\hline \multicolumn{6}{|c|}{ Coefficients $^{a}$} \\
\hline \multirow[b]{2}{*}{ Model } & \multicolumn{2}{|c|}{$\begin{array}{l}\text { Unstandardized } \\
\text { Coefficients }\end{array}$} & \multirow{2}{*}{$\begin{array}{c}\text { Standardized } \\
\text { Coefficients } \\
\text { Beta }\end{array}$} & \multirow[b]{2}{*}{$T$} & \multirow[b]{2}{*}{ Sig. } \\
\hline & $B$ & Std. Error & & & \\
\hline $1 \quad$ (Constant) & 1,553 & 5,211 & & ,298 & ,766 \\
\hline Online Business Learning & ,213 & ,056 & ,351 & 3,811 & ,000 \\
\hline Parental & ,308 & ,092 & ,298 & 3,349 &, 001 \\
\hline Locus of Control & ,486 & 148 & 251 & 3,287 & ,001 \\
\hline
\end{tabular}

(Source: Primary Data Processed by Researchers, 2020) 
Based on the coefficients table, the regression equation is shown as follows:

$$
Y=1,553+0,213 X_{1}+0,308 X_{2}+0,486 X_{3}
$$

The interpretation of the multiple regression equation stated that if the value of the $X_{1}, X_{2}$, dan $X_{3}$ variables is 0 the $Y$ value is 1,553 . The regression coefficient value of all independent variables consisting of online business learning $\left(X_{1}\right)$, parental $\left(X_{2}\right)$, and locus of control $\left(X_{3}\right)$ has a positive coefficient value which indicates that all independent variables have a positive influence on the dependent variable, namely online entrepreneurial interest $(Y)$. The regression coefficient value of the online business learning variable $\left(X_{1}\right)$ of 0,213 indicates that every time there is an increase in one unit of online business learning variable activity through the assumption that other independent variables are constant will result in an increase in the interest variable in online entrepreneurship by 0,213 units. The regression coefficient value of the parental variable $\left(X_{2}\right)$ is 0,308 , indicated there is an increase in one unit of parental variable activity with the assumption that the other independent variables are constant results in an increase in the interest in entrepreneurship online by 0,308 units. The regression coefficient value of the locus of control variable $\left(X_{3}\right)$ is 0,486 , indicating that each increase of one unit of activity for the locus of control variable with the assumption that the other independent variables are constant will result in an increase in the interest variable in entrepreneurship online by 0,486 units.

\section{Test F (simultaneous)}

This study used the $F$ test to determine whether the online business learning variables $\left(X_{1}\right)$, parental $\left(X_{2}\right)$, and locus of control $\left(X_{3}\right)$ simultaneously affect the online entrepreneurial interest variable $(\mathrm{Y})$.

Based on the results of statistical calculations through SPSS 25 , the F test results are as follows:

Table 3 F Test Results

ANOVAa

\begin{tabular}{|c|c|c|c|c|c|c|}
\hline \multicolumn{2}{|c|}{ Model } & Sum of Squares & Df & Mean Square & $F$ & Sig. \\
\hline 1 & Regression & 3429,178 & 3 & 1143,059 & 43,529 &, $000^{\mathrm{b}}$ \\
\hline & Residual & 2652,213 & 101 & 26,260 & & \\
\hline & Total & 6081,390 & 104 & & & \\
\hline
\end{tabular}

(Source: Primary Data Processed by Researchers, 2020)

Based on the SPSS test, the $F$ test results obtained were 43,529. This value was greater than the value of the $\mathrm{F}$ table with degrees of freedom $(105-3)=102$ obtained by the $\mathrm{F}$ table of 2,69 . The result of the calculation of the probability value is 0,00 or less than 0,05 so that $\mathrm{H}_{0}$ is rejected and $\mathrm{H}_{1}$ is accepted. The conclusion is that there is a positive and significant influence on online business learning, parental, and locus of control simultaneously on the interest in online entrepreneurship.

\section{Test $\mathbf{t}$ (partial)}

This test is used to partially test each variable. The results of this test are seen from the table of coeficients in the column sig (significance) 
Based on the results of statistical calculations through SPSS 25, the t test results are as follows:

Table $4 \mathrm{t}$ test results

Coefficients $^{a}$

\begin{tabular}{|c|c|c|c|c|c|c|}
\hline \multirow{2}{*}{\multicolumn{2}{|c|}{ Model }} & \multicolumn{2}{|c|}{$\begin{array}{l}\text { Unstandardized } \\
\text { Coefficients }\end{array}$} & \multirow{2}{*}{$\begin{array}{c}\text { Standardized } \\
\text { Coefficients } \\
\text { Beta } \\
\end{array}$} & \multirow[b]{2}{*}{$t$} & \multirow[b]{2}{*}{ Sig. } \\
\hline & & B & Std. Error & & & \\
\hline 1 & (Constant) & 1,553 & 5,211 & & 298 & ,766 \\
\hline & Online Business Learning & ,213 & ,056 & ,351 & 3,811 &, 000 \\
\hline & Parental & ,308 & ,092 & ,298 & 3,349 &, 001 \\
\hline & Locus of Control & ,486 & ,148 & ,251 & 3,287 &, 001 \\
\hline
\end{tabular}

(Source: Primary Data Processed by Researchers, 2020)

Based on the coefficients table above, it can be seen that:

1. Results of Online Business Learning t Test $\left(X_{1}\right)$

Based on the SPSS test, the results of the $t_{\text {count }}>t_{\text {table }}$ were $3,811>1,983$ with a probability value calculation of $0,00<0,05$. Based on the $t$ value and the probability value, it can be concluded that $\mathrm{Ho}$ is rejected and $\mathrm{Ha}$ is accepted, meaning that the online business learning variable partially on the interest in online entrepreneurship has a positive and significant effect.

2. Parental t Test Result $\left(\mathrm{X}_{2}\right)$

Based on the SPSS test, the results of the $t_{\text {count }}>t_{\text {table }}$ were $3,349>1,983$ with a probability value calculation of $0,01<0,05$. Based on the $t$ value and the probability value, it can be seen that $\mathrm{Ho}$ is rejected and $\mathrm{Ha}$ is accepted, which means that partially parental variables on the interest in online entrepreneurship have a positive and significant effect.

3. Result of $t$ Test Locus of Control $\left(\mathrm{X}_{3}\right)$

Based on the SPSS test, the results of the $t_{\text {count }}>t_{\text {table }}$ were 3,287 $>1,983$ with a probability value calculation of $0,01<0,05$. Based on the $t$ value and the probability value, it can be seen that $\mathrm{Ho}$ is rejected and $\mathrm{Ha}$ is accepted, which means that the partial locus of control variable on the interest in online entrepreneurship has a positive and significant effect.

\section{Coefficient of Determination (R Square)}

The coefficient of determination analysis is used to determine the magnitude of the influence of the independent variable on the dependent variable and to determine the percentage of the total variation in the dependent variable which is explained in the independent variable in a multan way.

The results of the determination coefficient test are as follows:

Table 5 Results of the Determination Coefficient Test

\begin{tabular}{ll|r|r|r} 
& \multicolumn{4}{c}{ Model Summary } \\
Model & $\mathrm{R}$ & $R$ Square & Adjusted $R$ Square & Std. Error of the Estimate \\
\hline 1 &, $751^{\mathrm{a}}$ &, 564 &, 551 & 5,124 \\
\hline
\end{tabular}

(Source: Primary Data Processed by Researchers, 2020) 
Based on the calculation of the Summery above model, it is known that the $R$ Square number is 0,564 or $56,4 \%$. The result shows that the effect of online business learning, parental, and locus of control on the interest in entrepreneurship online is $56,4 \%$, while the rest $(100 \%-56,4 \%=43,6 \%)$ can be influenced by other factors outside of online business learning, parental, and locus of control. Effective contribution and relative contribution are used to find out how pure each independent variable is to the dependent variable. Effective contribution of online business learning $\left(X_{1}\right)$ 23,6\%, parental $\left(X_{2}\right) 19 \%$ and locus of control $\left(X_{3}\right) 13,8 \%$.

\section{DISCUSSION}

\section{The Effect of Online Business Learning, Parental, and Locus of Control on Online Entrepreneurial Interest}

Based on the first hypothesis test through the $F$ test, the $F$ test results obtained were 43,529 , this value was greater than the Ftable value of 2,69 . The result of the calculation of the probability value is 0,00 or less than 0,05 so that $\mathrm{H}_{0}$ is rejected and $\mathrm{H}_{1}$ is accepted. It can be concluded that there is a positive and significant influence between online business learning, parental, and locus of control simultaneously on the interest in online entrepreneurship in Vocation High School 1 Karanganyar in the academic year 2020. R square is 0,564 , meaning that the effect of online business learning, Parental, and locus of control simultaneously have an influence on the interest in online entrepreneurship by $56,4 \%$. The amount of influence is not $100 \%$ so that the remaining $43,6 \%$ is influenced by variables other than this research variable.

Based on the results of the analysis, it can be seen that learning online business, parental, and high locus of control would have increased interest toward students's entrepreneurship online. Interesting in entrepreneurship online is someone's interest in something in the field of business online to get the expected results or benefits.

\section{The Effect of Online Business Learning on Online Entrepreneurial Interest}

The second hypothesis testing is done by doing the test with the results of $t_{\text {count }}>t_{\text {table, }}$ namely $3,811>1,983$ with a probability value calculation of $0,00<$ 0,05 . Based on the $t$ value and the probability value, it can be interpreted that $\mathrm{Ho}$ is rejected and $\mathrm{H}_{2}$ is accepted, which means that there is a positive and significant effect of online business learning partially on the interest in online entrepreneurship, therefore giving online business learning needs to be taught at Vocational High School. In addition, providing online business learning to Vocational High School students will encourage students to do entrepreneurship online because online entrepreneurship is not binding and flexible or free, where most students like freedom (Wang \& Lin, 2016). That is happened because relentless convergence between entrepreneurship. and digital technology has given rise to a new generation of entrepreneurs who apply digital technology to carry out most of the processes required to launch a new business (Giones \& Brem, 2017).

These results are in line with research conducted by Fadhilah et al (2016), namely the existence of the positive and significant influence that occurs between online marketing learning on the interest in online entrepreneurship with the research subject in class XI students majoring in marketing at Vocation High School Surakarta. It can be explained that online marketing learning has an important role in increasing students' interest in online entrepreneurship in the marketing skills competency of class XI at Vocation High School Surakarta. 


\section{The Effect of Parental on Online Entrepreneurial Interest}

The third hypothesis testing is done by doing the test with the results of $t_{\text {count }}$ $>t_{\text {table }}$ which is $3,349>1,983$ with a probability value calculation of $0,01<0,05$. Based on the $t$ value and the probability value, it is concluded that Ho is rejected and $\mathrm{H}_{3}$ is accepted, meaning that there is a positive and significant parental and partial influence on the interest in online entrepreneurship.

Based on the research, most students argued that the role of parents in every decision made was great. Family has various roles in establishing children, one of them is the role of parents in making a big contribution to children, that is fulfilling the child's needs, such as the opinion of Jigyel et al (2019) that parents have an important role in meeting the basic needs not including their educational needs.

The results of the study are in line with research conducted by Dusak \& Sudiksa, (2016), Setiawan \& Sukanti (2019) and Sucipto (2019), which explained that there is a positive and significant relationship regarding the influence of parental and family environment on interest in online entrepreneurship where readiness in entrepreneurship is influenced by guidance and direction from parents to have an entrepreneurial attitude.

4. Effect of Locus of Control on Online Entrepreneurial Interest

The fourth hypothesis testing is done by doing the test with the results of $t_{\text {count }}$ $>t_{\text {table }}$ which is $3,287>1,983$ with a probability value calculation of $0,01<0,05$. Based on the $t$ value and the probability value, it can be concluded that $\mathrm{Ho}$ is rejected and $\mathrm{H}_{4}$ is accepted which means that there is a positive and significant effect of partial locus of control on the interest in online entrepreneurship.

It means that the locus of control variable individually has a significant effect on students' online entrepreneurship interest in marketing. Based on the results of research, students tend to believe in their own abilities in achieving their work. Students believe that they can become entrepreneurs with the abilities they have, but they also believe that external forces such as relationships will also influence them in working and entrepreneurship online. One of the characteristics of an entrepreneur according to Edvarson in Riani (2014: 12) is an entrepreneur must have an internal locus of control, meaning that an entrepreneur must have the attitude or determination in dealing with all situations and conditions faced. Attitude and personality are important elements as a basis for achieving goals and results. The results of other studies are in line with those conducted by Dusak \& Sudiksa (2016), which explains that there is a positive and significant relationship regarding the influence of locus of control on entrepreneurial interest which is influenced by existing abilities.

\section{CONCLUSION}

Based on the research results that have been described, it can be concluded that, there is a positive and significant influence between online business learning, parental, and locus of control on students' interest in online entrepreneurship. That means any increasing in online business learning, parental, and student locus of control will also be followed by an increase in online entrepreneurial interest. The magnitude of the influence of online business learning, parental, and locus of control on the interest in online entrepreneurship is $56,4 \%$, while the remaining $43,6 \%$ can be influenced by other factors outside of online business learning, parental, and locus of control, with the results of their effective contribution in each online business learning $\left(X_{1}\right) 23,6 \%$, parental $\left(X_{2}\right) 19 \%$ and locus of control $\left(X_{3}\right) 13,8 \%$ on the interest in online entrepreneurship. 


\section{REFERENCES}

Alma, B. (2010). Kewirausahaan. Bandung: Alfabeta.

Asosiasi Penyelenggara Jasa Internet Indonesia (APJII). (2018). Penetrasi dan Profil

Pelaku Pengguna Internet Indonesia. Polling Indonesia.

Badan Pusat Statistik (BPS). (2019). Pengangguran Terbuka menurut Pendidikan Tertinggi yang Ditamatkan 1986-2018. https://www.bps.go.id/statictable/2009/04/16/972/pengangguran-terbukamenurut-pendidikan-tertinggi-yang-ditamatkan-1986---2018.html diakses pada tanggal 2 Januari 2020.

Dusak, I., \& Sudiksa, I. (2016). Pengaruh Pendidikan Kewirausahaan, Parental, Dan Locus of Control Terhadap Niat Berwirausaha Mahasiswa. E-Jurnal Manajemen Universitas Udayana, 5(8), 255309.

Fadhilah, S., Wahyuni, S., \& Nugroho, jonet A. (2016). Pembelajaran Pemasaran Online, Self Efficacy Dan Minat Berwirausaha Online Kelas Xi Pemasaran Smk Negeri Surakarta. Pendidikan Ekonomi, FKIP Universitas Sebelas Maret, 2(2), 118.

Fadli, R. P., Mudjiran, M., Ifdil, I., \& Amalianita, B. (2019). Peluang dan tantangan bimbingan karir di sekolah menengah kejuruan pada era revolusi industri 4.0. Jurnal EDUCATIO: Jurnal Pendidikan Indonesia, 5(2), 102. https://doi.org/10.29210/120192395

Giones, F., \& Brem, A. (2017). Digital Technology Entrepreneurship: A Definition and Research Agenda. Technology Innovation Management Review, 7(5), 44-51. https://doi.org/10.22215/timreview1076

Happy, M., \& Chabib, S. (2021). Pemanfaatan Media Sosial Terhadap Minat Berwirausaha Siswa Kelas Xii Bdp Di Smk Negeri 1 Surabaya. 9(2), 1209-1215.

Indriyani, L., \& Margunani, M. (2019). Pengaruh Kepribadian, Pendidikan Kewirausahaan, Dan Lingkungan Keluarga Terhadap Minat Berwirausaha. Economic Education Analysis Journal, 7(3), 848-862. https://doi.org/10.15294/eeaj.v7i3.28315

Irawansyah. (2020). KEWIRAUSAHAAN TERHADAP MINAT BERWIRAUSAHA SISWA SMK NEGERI 1 KOTA BIMA. 1(1), 1-13.

Jigyel, K., Miller, J. A., Mavropoulou, S., \& Berman, J. (2019). Parental Involvement in Supporting Their Children with Special Educational Needs at School and Home in Bhutan. Australasian Journal of Special and Inclusive Education, 43(01), 54-68. https://doi.org/10.1017/jsi.2019.3

Pannells, T. C., \& Claxton, A. F. (2008). Happiness, creative ideation, and locus of control. Creativity Research Journal, 20(1), 67-71. https://doi.org/10.1080/10400410701842029

Prima, I., M., Rusdarti, \& Pujiati, A. (2015). Pengaruh Sikap Dan Pengetahuan Kewirausahaan Terhadap Kesiapan Berwirausaha Melalui Self-Efficacy. The Journal of Economic Education, 4(1), 8-13.

Setiawan, D., \& Sukanti. (2019). Pengaruh Ekspektasi Pendapatan, Karakteristik Individu Dan Pendidikan Kewirausahaan Terhadap Minat Berwirausaha. Jurnal Profita: Kajian IImu Akuntansi, 4(7), 1-12. http://journal.student.uny.ac.id/ojs/index.php/profita/article/view/5990/5724

Sucipto, E. E. (2019). Minat Ibu Rumah Tangga Berwirausaha Secara Online. Agora:; $7(2014)$.

Suryadi. (2019). Kewirausahaan dan Pemberdayaan Pemuda Dalam Mengurangi Pengangguran. Jurnal Ketenagakerjaan, 14(1), 54-67. http://journals.kemnaker.go.id/index.php/naker/article/view/55 
Wang, Y.-M., \& Lin, Y.-S. (2016). Determinants of Internet Entrepreneurship Intentions among Business School Students. International Journal of Information and Education Technology, 6(10), 754-758. https://doi.org/10.7763/ijiet.2016.v6.787

Jaedun, A., Khaizer, M., O., Kartowagiran, B., \& Istiyono, E. (2020). A Precedence Evaluation of Demand and Supply Between Vocational High School Graduates and Workforce Requirement in Indonesia. Jurnal Penelitian dan Evaluasi Pendidikan, 24 (1), 27-38.

Riani, L. K. (2014). Dasar-dasar Kewirausahaan. Bandung: Alfabeta.

Valerio, A., Parton, B., \& Robb, A. (2014). Entrepreneurship Education and Training Programs Around the World (Dimensions for Success). Washington D.C: The World Bank.

Zigarmi, D., Galloway, F. J., \& Roberts, T.P. (2018). Work Locus of Control, Motivational Regulation, Employee Work Passion, and Work Intentions: An Empirical Investigation of an Appraisal Model. Journal of Happiness, 19 (1), 231-256. 